\title{
Life-history characteristics of Pseudoplatystoma metaense (Teleostei: Siluriformes: Pimelodidae) from the northwestern Orinoco River Basin
}

\author{
Alfredo Pérez ${ }^{1}$ and Nidia Noemí Fabré ${ }^{2}$
}

The tiger shovelnose catfish (Pseudoplatystoma metaense) identified in literature prior to 2007 as P. tigrinum is the most important catfish species in the Orinoco River fishery, because of its abundance and high market price. The aim of this study was to obtain age, growth and population parameters of the of tiger shovelnose catfish. A total of 2,183 catfish, were sampled during 1996-2003 from the commercial fishery of the northwestern Orinoco River Basin in Venezuela, and were aged by examination of otoliths. Validation of otolith annuli was achieved with marginal increment analysis. Results suggest that, the opaque and translucent zones of otoliths were formed once per year. Length-weight relation and the von Bertalanffy growth model parameters were used to evaluate growth and other population parameters. A strong link between the annual flood pulse and opaque zone formation was confirmed in tiger shovelnose catfish. The total mortality $(Z)$ and natural mortality $(M)$ were estimated. Based in the reference points for optimal and limit fishing mortality rates $\left(F_{\text {opt }}\right.$ and $\left.F_{\text {limit }}\right)$ this species is exploited above optimum levels. We thus recommend a closed fishing season during their seasonal reproduction, and establishment of a system of fish refuges to help sustain the population.

Keywords: Age, Growth, Otoliths, Overfishing, Venezuela.

O bagre capararí (Pseudoplatystoma metaense) identificado na literatura antes de 2007 como P. tigrinum é uma das espécies de bagres mais importantes da pesca no noroeste do rio Orinoco, por sua abundância e alto preço de comercialização no mercado. O objetivo deste estudo foi obter parâmetros populacionais sobre a idade e crescimento do bagre capararí. Um total de 2.183 exemplares de P. metaense foram examinados desde 1996 até 2003, coletados da frota comercial artesanal do rio Apure na Venezuela. A idade foi determinada pela examinação dos otólitos. A validação da idade foi estimada com a análise de incremento marginal. As zonas opacas e translúcidas dos otólitos foram formada anualmente. A relação comprimento-peso e a equação de von Bertalanffy foram usadas para avaliar o crescimento e outros parâmetros populacionais. Uma forte relação entre o pulso anual de inundação e a formação de zonas opacas foi confirmada em P. metaense. A mortalidade total $(Z)$ e a mortalidade natural $(M)$ foram estimadas. Portanto, baseado nos pontos de referência biológicos $\left(F_{\text {opt }}\right.$ e $\left.F_{\text {lim }}\right)$ esta espécie encontra-se sobreexplotada acima do nível ótimo. Recomenda-se que o período de defeso deva ser sincronizado com o período de reprodução da espécie e um sistema de reservas de pesca deveria ser utilizado para ajudar a sustentabilidade da população.

Palavras-chave: Crescimento, Idade, Otólito, Sobrepesca, Venezuela.

\section{Introduction}

The large-bodied catfishes of the family Pimelodidae are among the dominant commercial species in the Orinoco River Basin, forming an important part of the landed catch in inland fisheries (Castillo et al., 1988; Novoa, 2002). In Venezuela, these highly valued resources are marketed whole, usually fresh on ice, at markets in various state capitals. They are also seasonally exported to Colombia (Novoa, 2002).
In the inland fisheries of Venezuela, the "bagres rayados" (Pseudoplatystoma orinocoense Buitrago-Suárez \& Burr, 2007 and P. metaense Buitrago-Suárez \& Burr, 2007, in literature prior to 2007 identified as $P$. fasciatum and $P$. tigrinum, respectively) have composed on average $15.7 \%$ of the landed catch from 1996 to 2003 (contributing on average $6,121 \mathrm{t}^{\mathrm{year}}{ }^{-1}$ ).

The tiger shovelnose catfish Pseudoplatystoma metaense Buitrago-Suárez \& Burr, 2007, occurs in benthic or near bottom habitats of main rivers throughout the Orinoco Basin

${ }^{1}$ Laboratorio de Biología, Programa Ciencias del Agro \& Mar UNELLEZ-APURE, San Fernando, ZP 7001, Edo. Apure, Venezuela. piracatinga@yahoo.com.br, ๑http://orcid.org/0000-0002-4954-2236 (corresponding author)

${ }^{2}$ Instituto de Ciências Biológicas e da Saúde (ICBS), Setor Ecologia e Conservação, Universidade Federal de Alagoas, 57072-900 Maceió, AL, Brazil. tchoni1@uol.com.br 
and it is landed in commercial quantities from all along the Apure River (Barbarino Duque, Winemiller, 2003; Castillo et al., 1988; Machado-Allison, 1987; Novoa, 2002).

There is a lack of reliable information on the longevity, growth parameters, mortality rates, and population characteristics of $P$. metaense, despite its ecological and commercial importance. The juveniles inhabit floodplain areas (inundated savannas) of the Apure River (Barbarino, 2005). In Venezuela, there has been only one study on age and growth of $P$. metaense but without age validation (Reid, 1983).

The accurate determination of fish age is the key to estimating growth and mortality rates (Beamish, Fournier, 1981; Marriott, Cappo, 2000). Errors in determining fish age can result in ambiguous demographic parameters and provide misleading impressions of the production potential of fish stocks (Brothers, 1983).

This work represents the first comprehensive study of age, growth, and mortality of $P$. metaense from the northwestern Orinoco River Basin; it is based on age estimates from asterisci otoliths. Results will be important for sustainable management of this economically important fishery resource.

\section{Material and Methods}

Commercial landings of Pseudoplatystoma metaense from the northwestern Orinoco River Basin were sampled opportunistically from July 1996 to December 2003 (Fig.1). Samples obtained from January 2000 to December 2003 were collected on a monthly basis among all fishing boats in the artisanal fleet from the lower Apure River.

Specimens were compared with reference collections of this species in the Museo de Ciencias Naturales de Guanare of Universidad Nacional Experimental de los Llanos Occidentales Ezequiel Zamora (e.g., voucher MCNG 31287 , Laguna Tineo, $08^{\circ} 11^{\prime} 25^{\prime \prime} \mathrm{N} 63^{\circ} 28^{\prime} 20^{\prime \prime} \mathrm{W}$, Orinoco River, Anzoátegui, Venezuela) to verify identification.

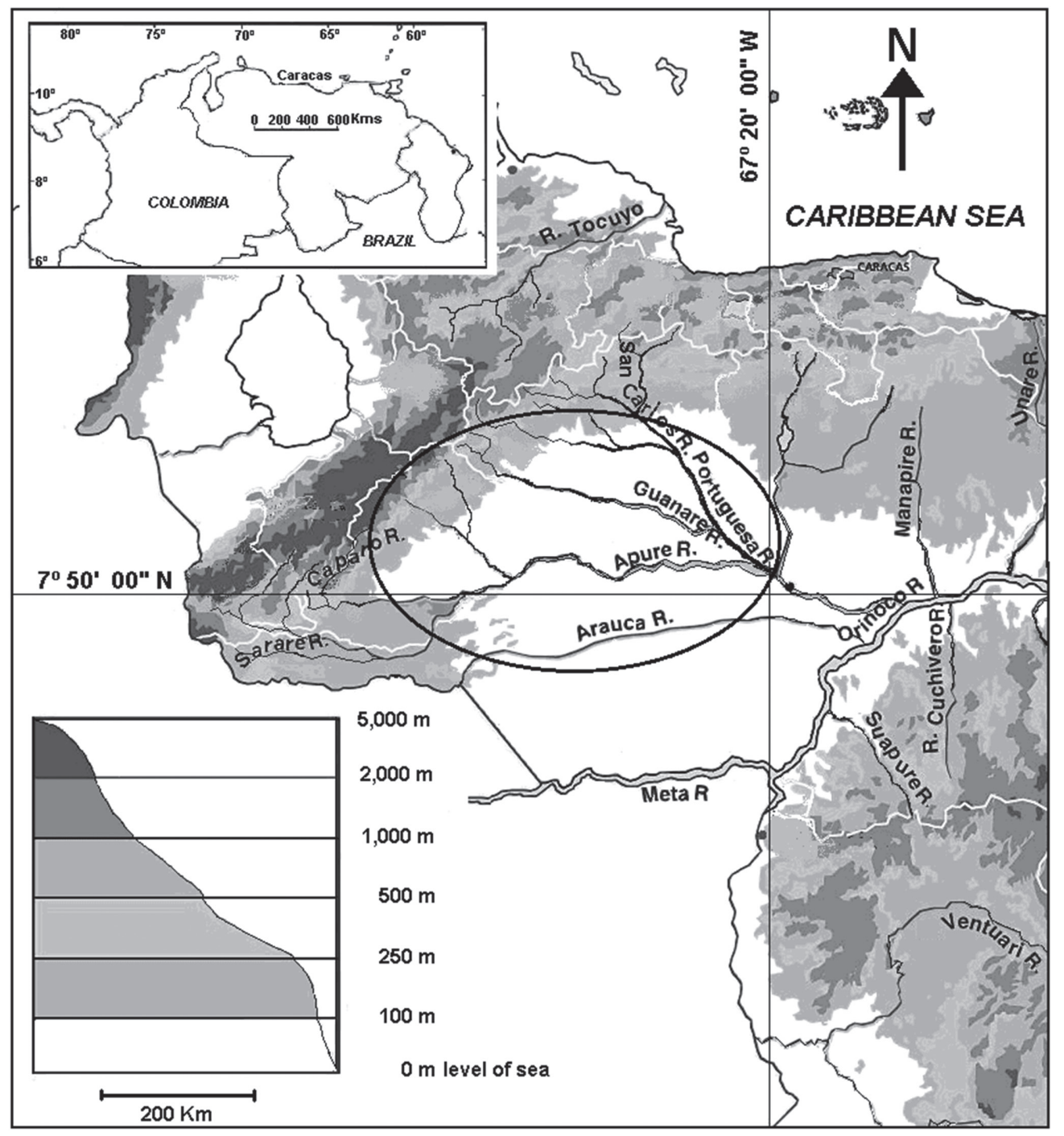

Fig. 1. Location of the sampling points in the study area of the northwestern Orinoco River Basin of the fishery for Pseudoplatystoma metaense. 
All specimens were captured with gillnets ( $3 \mathrm{~m} \times 120 \mathrm{~m} \mathrm{x}$ $8 \mathrm{~cm}$ stretch mesh) along the main river channel. Additional juvenile specimens were obtained by our research team using gillnets of $3 \mathrm{~cm}$ stretch mesh.

For all fish, total length $(T L, \mathrm{~cm})$ was measured from tip of upper jaw to tip of longest caudal lobe, eviscerated weight ( $W_{e v}$ to nearest $\mathrm{g}$ ) was recorded, and whenever possible, sex was determined by examination of the gonads. The relationships between $T L$ and $W_{e v}$, were described by the power function: $W_{e v}=a^{*} T L^{b}$, where: " $a$ " and " $b$ " are regression coefficients from simple linear regression. These relationships were fitted to $\log _{10}$-transformed data. An analysis of covariance (ANCOVA) was used to determine if there were significant differences $(\mathrm{P}=0.05)$ in the $T L$ versus $W_{e v}$ relationships between sexes for $P$. metaense. Multiple comparisons were performed with Least Significant Difference test (LSD; Sokal, Rohlf, 1981). Trends in length and weight relationships of fish over time also were assessed using ANCOVA.

Otolith preparation and analysis. Otolith removal, measurement, and preparation followed the procedures described by Pérez, Fabré (2003). All age estimates were based on the analysis of growth annuli in asteriscus otoliths. The whole otoliths were examined under a Leica MZ5 stereoscopic microscope at 1.65x magnification with reflected light on a black background.

Otolith images were recorded using a digital video camera connected to the microscope. The images were saved as bitmap file (format bmp 24bit) and processed with the program Image Pro Express ver. 4.0 (Copyright (C) Media Cybernetics Inc.).

Age validation. Marginal Increment Analysis (MIA) provides a measure of the seasonal growth using the relative amount of growth that occurred since the last annulus was formed (Balboni et al., 2011; Fabré, Saint-Paul, 1998).

$$
M I A=\left(\mathrm{R}_{\mathrm{t}}-\mathrm{R}_{\mathrm{n}}\right) /\left(\mathrm{R}_{\mathrm{n}}-\mathrm{R}_{\mathrm{n}-1}\right) .
$$

Where: $R_{t}=$ total radius of otolith; $\mathrm{R}_{\mathrm{n}}=$ distance from focus of otolith to last annulus; and $\mathrm{R}_{\mathrm{n}-1}=$ distance from focus to penultimate annulus. The MIA is appropriate only if all fish in the population lay down the translucent zone at about the same time. Thus, an annulus consists of a single opaque and a single translucent cycle over a 12-month period. The opaque zone is believed to form during periods of slow growth (Chilton, Beamish, 1982; Panfili et al., 2002; Volpedo, Vaz-dos-Santos, 2015).

An analysis of variance (ANOVA, one -way) was used to detect significant differences in average MIA among months and the post hoc test Least Significant Differences (LSD) was applied (Sokal, Rohlf, 1981). These data were compared with river levels ( $\mathrm{m}$ above sea level) during years 20002003, from the Ministerio del Ambiente y de los Recursos Naturales (MARN-Apure).
The periodic regression model is a useful tool to evaluate biological rhythms (Angelini et al., 1992). MIA data were fitted to a periodic regression model (Bliss, 1970) to evaluate possible periodic formation of mark in the otoliths, using the following equation:

$$
\mathrm{y}=\alpha+\beta_{1} * \cos (\theta)+\beta_{2} * \operatorname{sen}(\theta)+\delta
$$

Where: $\mathrm{y}=$ dependent variable; $\beta=$ regression coefficient; $\alpha=$ mean general; $\theta=$ angular frequency $\left(2 \pi^{*} \mathrm{t} / \mathrm{k}\right) ; \mathrm{t}=$ independent variable; $\mathrm{k}=$ number of days or months; $\pi=\mathrm{pi} ; \delta=$ random error. The model was evaluated by the significance of the $\mathrm{F}$ value and analysis of studentized residuals (Kleinbaum et al., 1988). Parameters of the periodic model were estimated by a sub-routine (macro) implemented in spread sheet software.

Because the peak spawning period of $P$. metaense usually occurs in late May (Castillo et al., 1988; Pérez et al., 2012), all fish were assigned a birth date of 1 June to assure proper year-class identification. Ages were assigned from counts of annual growth increments consisting of alternating opaque and translucent rings from asteriscus otoliths (opaque rings were counted). Annual growth annuli were counted without reference to fish length or date of capture.

Each asteriscus otolith was read twice, with a separation of 15 days between each reading by the same reader. When the counts differed, these otoliths were re-examined a third time. Otoliths with structural irregularities (such as unusual calcification or deterioration of the ventral lobe) were considered doubtful and were excluded from the analysis.

The relationship between otolith size $(R \mathrm{t})$ and fish length $(T L)$ was tested using three different mathematical functions: linear, quadratic and exponential. The bestfit model was determined by analyzing the correlation coefficients of each function along with their residual distributions from the values of the dependent variable.

The precision of age estimates was calculated using the average percent error (APE) of Beamish, Fournier (1981). Greater precision is achieved as the $A P E$ is minimized $\left(A P E_{\mathrm{J}}=100 \% *\left(1 / R^{*} \Sigma\left(\left(X_{\mathrm{ij}}-X_{\mathrm{j}}\right) / X_{\mathrm{j}}\right)\right)\right)$. Where: $X_{\mathrm{ij}}$ is the $i$ th age determination of the $j$ th fish, $X_{\mathrm{j}}$ is the mean age estimate of the $j$ th fish, and $R$ is the number of times each fish is aged. When averaged across many fish, it becomes an index of average percent error.

Growth and mortality models. The von Bertalanffy growth function (VBGF) was fitted to estimates of lengthat-age with nonlinear least squares estimation procedures. The VBGF is defined by the equation:

$$
T L=L_{\mathrm{inf}} *\left[1-\exp -K^{*}\left(t-t_{0}\right)\right]
$$

Where: $T L=$ total length of fish of age $\mathrm{t} ; L_{\mathrm{inf}}=$ asymptotic length; $K=$ growth coefficient; $t=$ age of the fish; and $t_{0}=$ the hypothetical age at which the length is zero. 
Estimates of the instantaneous rate of total mortality $(Z)$ were obtained from the equation proposed by Beverton, Holt (apud. Sparre, Verema, 1995); we thus estimated $Z$ from the mean size in the catch

$$
Z=K^{*}\left(L_{\text {inf }}-L_{\text {mean }}\right) /\left(L_{\text {mean }}-L^{\prime}\right)
$$

Where: $L_{\text {mean }}=$ mean total length and $L^{\prime}=$ smallest total length fully represented in the sample (King, 1995).

To estimate the longevity $\left(T_{\max }\right)$ was used the equation proposed by Taylor (1958) (apud. Sparre, Verema, 1995):

$$
T \max =t_{0}+2.996 / \mathrm{K}
$$

Where $K$ and $t_{0}$ are parameters from VBGF. Instantaneous natural mortality rate $(M)$ was derived from the equation of Taylor (1958) (apud. Sparre, Verema, 1995).

$$
M=-\ln (1-0.95) / T_{\max }
$$

The annual percentage removal was estimated by the equation $\% R=\left[F / Z\left(1-\mathrm{e}^{Z}\right)\right]^{*} 100$, proposed by Tesch $(1971)$. Exploitation rates $(E)$ was derived from the estimates of $Z$ and $F$ as defined by the equation $E=F / Z$ where: $F=$ the instantaneous rate of fishing mortality derived from the relationship $F=Z-M$. Reference points for optimal and limit fishing mortality rates $\left(F_{\text {opt }}\right.$ and $\left.F_{\text {limit }}\right)$ were calculated for $P$. metaense by using the estimate of natural mortality $(M)$, where: $F_{\text {opt }}=0.5^{*} M$ and $F_{\text {limit }}=2 / 3 * \mathrm{M}$ (Patterson, 1992).

\section{Results}

A total of 2,183 specimens of Pseudoplatystoma metaense were analyzed in this study from those 1,914 (ranging in size from 20 to $121 \mathrm{~cm} \mathrm{TL}$ ) were examined for age analysis. Of the fish used for aging, 863 were males ranging from 20 to $107 \mathrm{~cm}$ TL and 1,051 were females ranging from 30 to $121 \mathrm{~cm} \mathrm{TL}$, an additional 269 (20-35 $\mathrm{cm}$ ) fishes had indeterminate sex.

Length-weight model. Length-weight relationships were calculated separately for males, females, and for both sexes combined (Tab. 1). Based on ANCOVA, the relationship between Wev and TL was not significantly different between sexes $(P>0.05)$, however, the length-weight ratio calculated by years (combined sexes) showed a good fit to the model ( $\mathrm{r}$ $>0.82$ ), and regression coefficients (b) ranged from 2.97 to 3.33. The covariance analysis (ANCOVA) showed significant differences between the years $(\mathrm{P}<0.05)$, observing a progressive decrease of the values in the analyzed period (Tab. 2).

Age validation. Otoliths displayed alternating opaque and translucent zones. A consistent annual trend was evident; the opaque zone was laid down during the low water period from January to March (dry season Fig. 2) and the translucent zone formed from April to December. Since the opaque and translucent zones are laid down once a year they represent valid annual growth marks. A periodical regression model was used to correlate the growth patterns in otoliths inferred from MIA with river level cycles. The model clearly showed the influence of annual flood cycle with a good fit of the data to the model $(\mathrm{r}=0.82$, s.e. $=0.07, P=0.01, \mathrm{n}=24)$. A secondary period of slowed MIA values was detected, for about AugustSeptember, but lowest MIA values were always found in February, when food may be limited and the reproductive period is starting (Fig. 2).

Tab. 1. Length-weight relationships for females, males and sexes combined of Pseudoplatystoma metaense from northwestern Orinoco River Basin; the combined relationship includes 269 young of year fishes with undetermined sex. Estimates of $a$ and $b$ is from the relationship $\log _{10}\left(\mathrm{~W}_{\mathrm{ev})}=\right.$ $\log _{10}(a)+b^{*} T L$; also presented are: correlation coefficient (r), standard error (S.E.), and sample size (n) for each regression.

\begin{tabular}{lccccc}
\hline Group & $\mathrm{a}$ & $\mathrm{b}$ & $\mathrm{r}$ & \pm S.E. & $\mathrm{n}$ \\
\hline Combined sex & -4.85 & 3.10 & 0.981 & 0.11 & 2183 \\
Female & -4.96 & 3.09 & 0.982 & 0.11 & 1051 \\
Male & -5.99 & 3.24 & 0.981 & 0.12 & 863 \\
\hline
\end{tabular}

Tab. 2. Inter-annual variation of Length-weight Relationship $\log _{10}\left(\mathrm{~W}_{\mathrm{ev}}\right)=\log _{10}(a)+b^{*} T L$; of Pseudoplatystoma metaense from northwestern Orinoco River Basin, showing: number of observation (n); intercept (a); regression coefficient $(b)$; correlation coefficient $(\mathrm{r})$; standard error (S.E.); critic value probability $(P)$.

\begin{tabular}{ccccccc}
\hline Years & $a$ & $b$ & $\mathrm{r}$ & \pm S.E. & $\mathrm{n}$ & $P$-critic \\
\hline 1996 & -6.09 & 3.33 & 0.948 & 0.08 & 356 & $<0.05$ \\
1997 & -5.12 & 3.16 & 0.936 & 0.56 & 462 & $<0.05$ \\
1998 & -4.74 & 3.07 & 0.970 & 0.14 & 300 & $<0.05$ \\
1999 & -4.53 & 3.02 & 0.822 & 0.53 & 313 & $<0.05$ \\
2000 & -4.37 & 2.97 & 0.961 & 0.10 & 243 & $<0.05$ \\
2001 & -4.76 & 2.93 & 0.901 & 0.17 & 123 & $<0.05$ \\
2002 & -4.18 & 2.91 & 0.964 & 0.28 & 204 & $<0.05$ \\
2003 & -4.96 & 3.01 & 0.975 & 0.14 & 183 & $<0.05$ \\
\hline
\end{tabular}

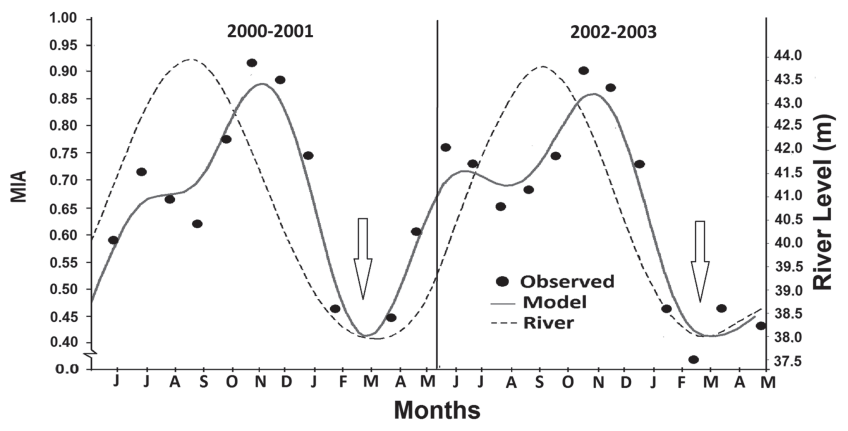

Fig. 2. Results of Periodic Regression Model fit to MIA values (dots) for asteriscus otoliths of Pseudoplatystoma metaense (solid line) compared with Apure River flood cycle (dashed line), for the periods June 2000-May 2001 and June 2002-April 2003. Arrows indicate approximate times of opaque zone (annulus) formation in the otoliths. 
Otolith structure and analysis. The quadratic model was the best predictor of fish length $(\mathrm{r}=0.92 ; \mathrm{sd}=0.129, \mathrm{n}=$ 146) with a minor heteroscedasticity observed in the residual distribution analysis. In contrast, the linear $(r=0.89, \mathrm{sd}=$ $7.98, \mathrm{n}=146)$ and exponential $(\mathrm{r}=0.91, \mathrm{sd}=0.135, \mathrm{n}=146)$ models were slightly less predictive.

Growth and mortality model. The precision of otolith readings of $P$. metaense between each reading was relatively high (7.9-11.2 \%). Given the variability observed among otoliths, this $A P E$ reflects a moderately high level of precision among otolith readings and indicates that the aging protocol adopted was replicable.

The von Bertalanffy growth function was fitted to TLat-age for each sex of $P$. metaense (Fig. 3). Growth in TL of $P$. metaense is relatively fast during the first two years, but is notably reduced in age cohorts beyond four years of age. For each sex, parameters of the VBGF and other population parameters are listed in Tab. 3. The sexes of $P$. metaense were not significantly different for TL-at-age ANCOVA $(P<0.05)$.

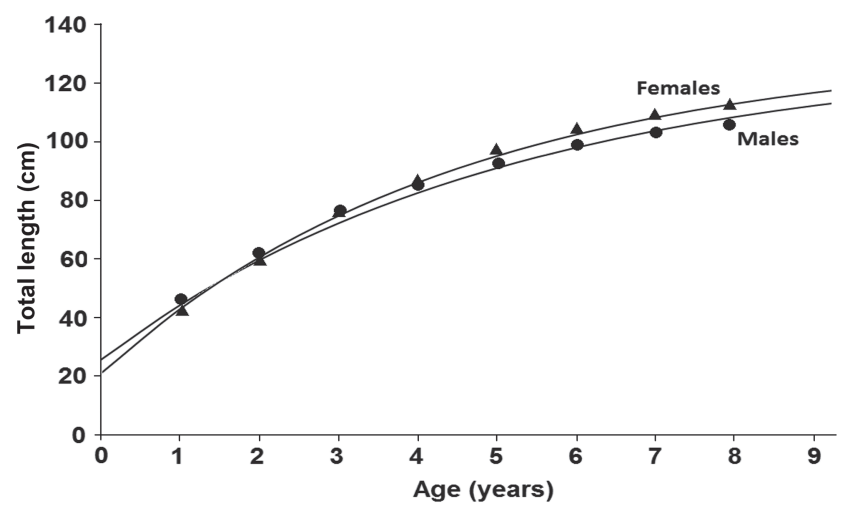

Fig. 3. Estimated von Bertalanffy growth curves for males (circles) and females (triangles) fitted to length-atage data from otoliths for Pseudoplatystoma metaense in northwestern Orinoco River Basin during 1996-2003 (model parameters presented in Tab.1).

Tab. 3. Summary of population parameters derived from the von Bertalanffy growth function with standard errors (S.E.) and others population parameters for each sex of Pseudoplatystoma metaense of the northwestern Orinoco River Basin ( $\mathrm{n}=861$ males, 1051 females).

\begin{tabular}{lcccc}
\hline Populations Parameters & Symbols & Male & Female & Unit \\
\hline Asymptotic total length & $L_{\text {inf }}$ & $\begin{array}{c}108.63 \\
( \pm 9.55)\end{array}$ & $\begin{array}{c}119.99 \\
( \pm 10.00)\end{array}$ & $\mathrm{cm}$ \\
Growth coefficient & $K$ & $\begin{array}{c}0.19 \\
( \pm 0.02)\end{array}$ & $\begin{array}{c}0.17 \\
( \pm 0.03)\end{array}$ & $1 / \mathrm{yr}$. \\
Constant of length at age zero & $t_{0}$ & -1.18 & -1.05 & \\
& & $( \pm 0.06)$ & $( \pm 0.08)$ & $\mathrm{cm}$ \\
Longevity & $T_{\max }$ & 12.37 & 15.68 & $\mathrm{yr}$. \\
Natural mortality coefficient & $M$ & 0.24 & 0.19 & \\
Total mortality coefficient & $Z$ & 1.83 & 2.08 & \\
\hline
\end{tabular}

The maximum observed age of $P$. metaense in the Orinoco River Basin was eight years. Given that the $P$. metaense, in the Apure River have been exploited for over 40 years, some age classes are absent, but using the equation of Taylor (1958) (apud. Sparre, Verema, 1995), to estimate the longevity $(T \max )$ it is possible that in an unfished population the longevity of $P$. metaense can reach the age of 15 years.

These two estimates of maximum age $\left(T_{\max }\right)$ in $P$. metaense were applied to the Taylor equation in order to derive an estimate of $M$. Consequently, $M$ was considered to be in the range of $0.19-0.24$, representing an annual survivorship of $70 \%$ for an unfished population.

The structure of the population of $P$. metaense in our study area is truncated. In 1996 (Fig. 4a) we observed a peak in year class 3 followed by relatively strong age classes 4-7. In subsequent years, however, abundances after year class 3 dropped off sharply, suggesting intense harvest of year class 4 and above (Figs. 4b-h); fishes older than age 7 years were rare. In most years, there was a strong mode of year class 3 reflecting the age at full recruitment to the commercial fishing (8 $\mathrm{cm}$ stretch mesh gillnets), since there were no changes in the selectivity of the fishing gear. Pseudoplatystoma metaense less than age 2 years were in general not fully recruited to the sampled population and were therefore excluded from mortality estimates (except for 2000-2001 and 2002-2003).

The year-specific total annual rate of mortality $Z$ of $P$. metaense in our study area was 0.65 for 1996-1997 (fishes aged 3-7 years), 2.78 for 1998-1999 (fishes aged 3-7 years), 1.60 for 2000-2001(fishes aged 2-7 years) and 3.40 for 2002-2003 fishes aged (2-7 years), representing an annual percentage removal of approximately $33.1 \%, 87.0 \%, 69.9 \%$ and $90.9 \%$, respectively, for each period (Tab. 3).

In addition, exploitation rates $(E)$ were: $0.69,0.92,0.87$, and 0.94 respectively. The optimum fishing mortality rate, $F_{\text {opp }}$ for $P$. metaense was estimated to be 0.22 , and the limit reference point, $F_{\text {limit }}$, was estimated to be 0.32 (Tab. 4). These results indicate that only approximately $20 \%$ of the available stock of $P$. metaense can be harvested on an annual basis in a sustainable manner and that annual harvest rates should not exceed $25 \%$ of the average stock size.

\section{Discussion}

The results of this study represent the first comprehensive study of age, growth, and mortality of Pseudoplatystoma metaense, based on age estimates from growth annuli of asteriscus otoliths. The asteriscus otoliths were determined to be valid structures for age determination in $P$. metaense. The seasonal patterns of MIA of individuals in older ages (3-7 years) exhibit clear trends conclusively confirming that those growth annuli are formed once per year (Fig. 2). We observed, however that experience of the observer/reader is a critical factor in increasing the agreement and hence precision of repeated counts of annual growth annuli in otolith of $P$. metaense. 
Tab. 4. Summary of total mortality $(Z)$, fishing mortality $(F)$ and exploitation rate $(E)$ for Pseudoplatystoma metaense derived from catch-at-age data for the northwestern Orinoco River Basin, based on ages determined from otoliths for the period 1996-2003. Estimates of annual removal percentage (\% R) and references points $F_{\text {opt }}$ and $F_{\text {limit }}$ (see text for definitions) are also presented.

\begin{tabular}{ccccccc}
\hline Years & $Z$ & $F$ & $E$ & \% Removal & $F_{\text {opt }}$ & $F_{\text {limit }}$ \\
\hline 1996 & 0.651 & 0.321 & 0.693 & 33.14 & & \\
1997 & 1.573 & 1.243 & 0.873 & 69.18 & & \\
1998 & 2.785 & 2.455 & 0.928 & 87.08 & & \\
1999 & 0.491 & 0.161 & 0.593 & 22.99 & 0.220 & 0.322 \\
2000 & 1.605 & 1.275 & 0.875 & 69.95 & & \\
2001 & 3.906 & 3.576 & 0.949 & 92.97 & & \\
2002 & 3.401 & 3.071 & 0.941 & 90.98 & & \\
2003 & 1.621 & 1.291 & 0.877 & 70.33 & & \\
\hline
\end{tabular}

The peak in opaque zone formation observed in our study during February-March is in accordance with the peak in opaque zone formation identified by García Vásquez et al. (2009) for Brachyplatystoma rousseauxii (Castelnau, 1855) in the Amazon River.

The periodic regression model showed an annual oscillation in the MIA to correlated with the flood pulse indicating a biological response. The translucent zone (the period of fast growth in the otoliths) is formed during the rising water, high water and falling water phases, in the months of April-December, and the opaque zone (the slow growth period) is formed in the low water period, which is the months of February and March. Furthermore, reproduction could play a significant role in timing of opaque zone formation in $P$. metaense because spawning occurs primarily in the low water and rising water phases (Barbarino, 2005; Castillo et al., 1988; Pérez et al., 2012). The MIA showed a good fit for $75 \%$ of the serial time used, nevertheless, the period from April 2001 to May 2002 was not significant due to the missing samples for four months. These results indicate that the river level cycle (flood pulse), doubtless in association with other factors, provides a stimulus that influences the endolymph fluid chemistry of these fishes, culminating in the formation of annual growth annuli.

Whereas fish of both sexes between two and four years of age were common in the landed catch, female and male fish older than seven years of age were uncommon. The maximum age of $P$. metaense observed in our study was much less than that reported previously. Reid (1983) reported ages in the range of 10 to 20 years for fishes from the upper Apure River based on counting of rings on vertebrae. Such variation in the longevity estimates by Reid (1983) could be related to the aging structure used. For example, growth marks representing annuli in vertebrae are often difficult to detect despite the presence of numerous discontinuities in bone growth (Marriott, Cappo, 2000).

The estimates of $k$ derived by Reid (1983) were less than half of those observed in this study, and the asymptotic length reported by Reid (1983) were notably larger than our estimations (Tab. 3). Clearly methodological differences in age estimation have the potential to unduly influence growth parameter estimation and may provide misleading impression of the growth potential of these fishes.

Based on otoliths, we found growth was relativity high throughout the first two years of life for both sexes. From age four onwards, however, somatic growths slowed steadily with increasing age. The estimation of growth parameters is dependent upon adequate sampling across the length range. The fishes sampled in our study ranged from 20 to $120 \mathrm{~cm}$ TL, covering most of the known TL range of $P$. metaense. It is thus, unlikely that our estimated growth parameters of $P$. metaense are biased because of incomplete sampling across the length range in the population.

The relatively long life span of $P$. metaense and other pimelodid catfish species have been observed by several authors (Ambrósio et al., 2003; Loubens, Panfili, 2000; Mateus, Petrere Júnior, 2004; Penha et al., 2004a, 2004b; Reid, 1983; Ruffino, Isaac, 1999) and such longevity may be an evolutionary adaptation that supports iteroparity in these species. Many Neotropical freshwater fish are highly fecund, but egg and larval survivorship are low; therefore, spawning over numerous years may be necessary to maintain stable populations.

In addition, numerous years of reproductive output may be required to contend with environmental variability (e.g., periodic climatic oscillations such as "El Niño"), which may substantially influence recruitment success from year to year.

Extended periods of high exploitation often results in decreases in the spawning stock biomass and truncation of the age structure of fish populations (see Fig. 4), that can diminish the number of effective spawnings per average individual over their life-span. Any reduction in the number of effective spawnings may result in a decrease in fitness and hence limit the adaptive capacity of the species to resist anthropogenic or environmental induced stresses such as dams, water pollution, and aquatic habitat fragment (van Oerzee, Rijnsdorp, 2015; Stergiou, 2002; Allan et al., 2005).

Fishery management implications. Throughout much of its range, $P$. metaense comprises a dominant proportion of the inland catch in multispecies fisheries of the northwestern Orinoco River Basin. Within these fisheries, P. metaense is taken both as part of the directed target catch and/or as a part of the retained catch. In gillnet-based fisheries, $P$. metaense has been harvested at all stages of their life history from juvenile to adult, making them especially vulnerable to overexploitation (Pérez-Lozano, Barbarino, 2013). We advocate that to ensure the sustainable exploitation rates of $P$. metaense, it is necessary to restrict the harvesting targets, focusing the capture only in the adult individuals, which should be done by changing the capture methods and through compliance of existing fishing regulations. 
a

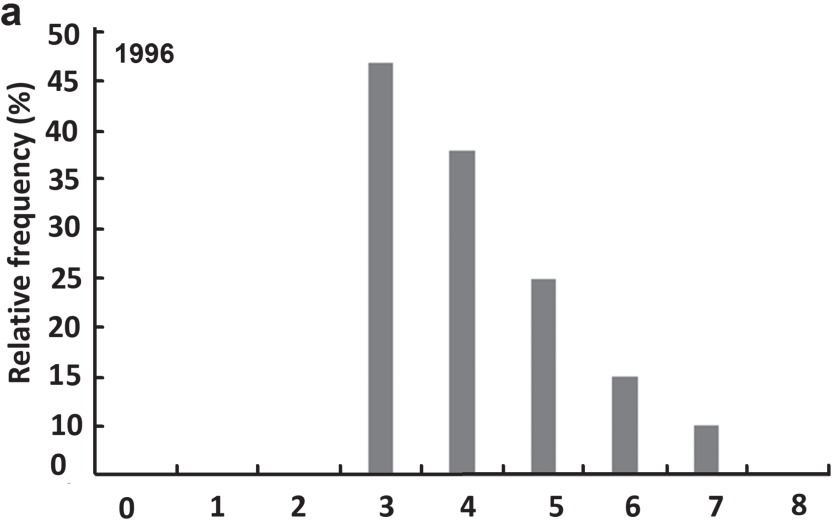

b

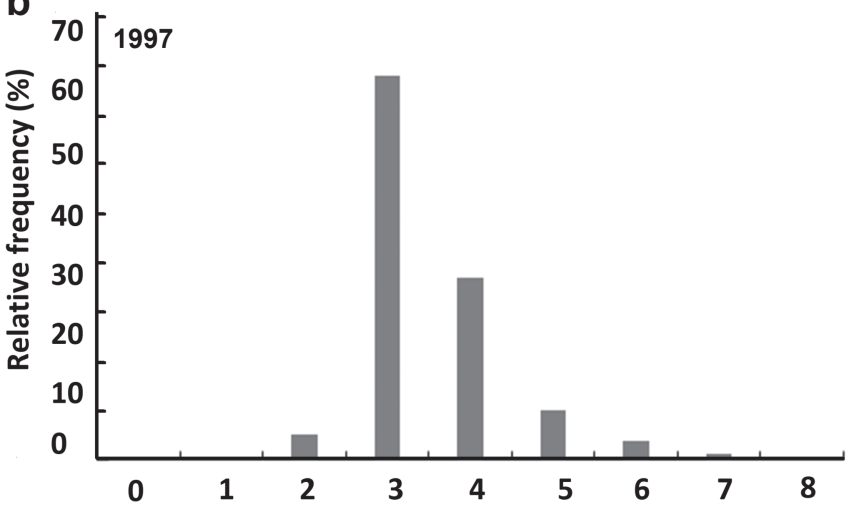

C

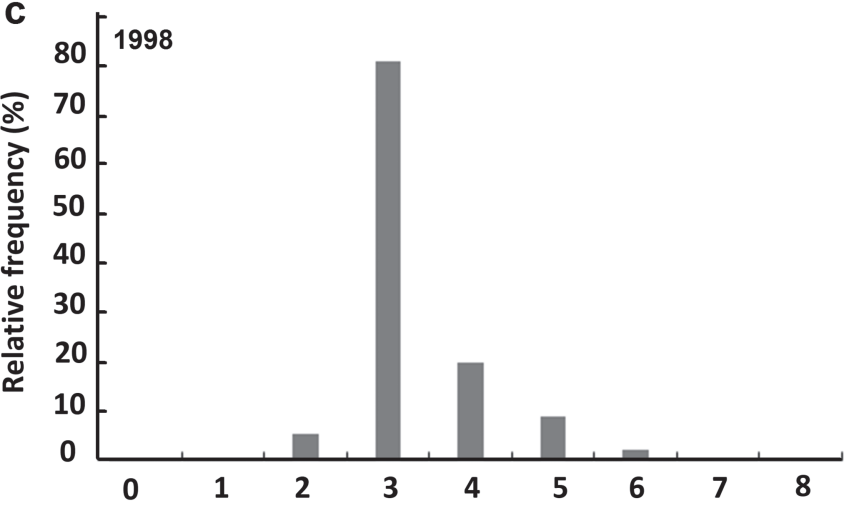

d

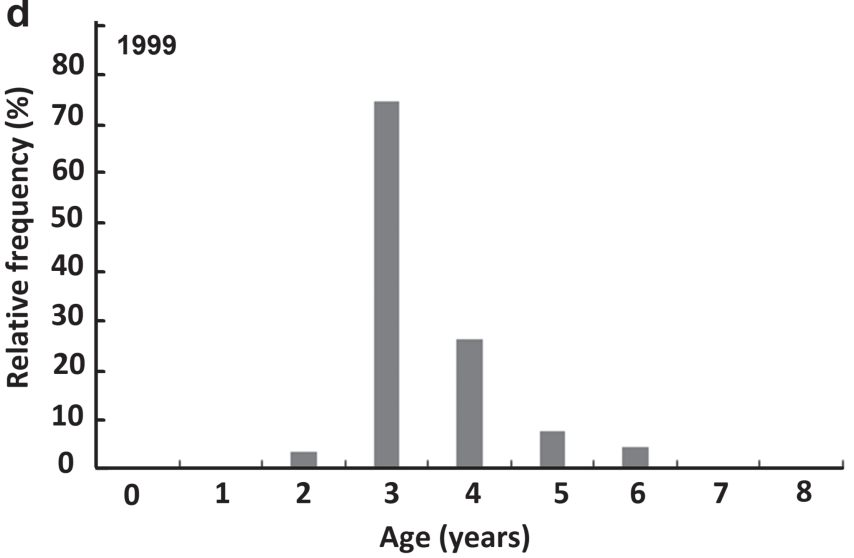

e
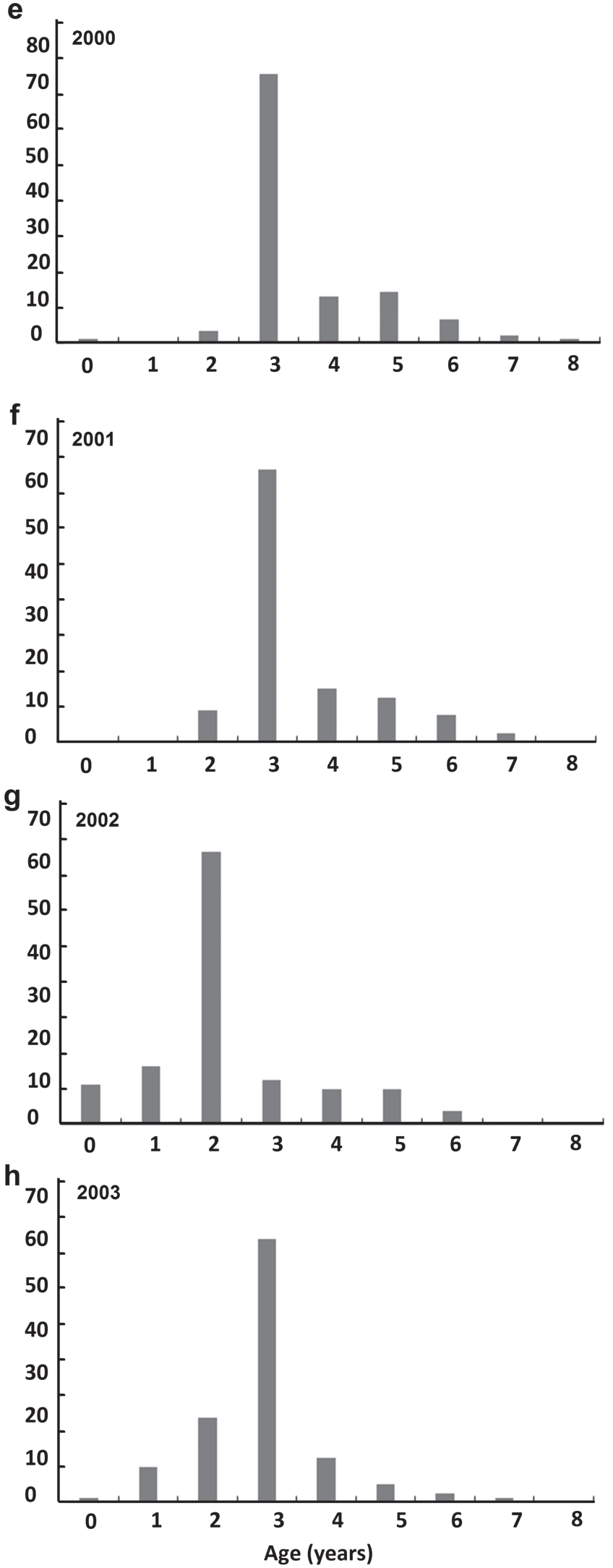

Fig. 4. Age-frequency distributions of Pseudoplatystoma metaense in the northwestern Orinoco River Basin fishery from different years: a)1996; b)1997; c) 1998; d) 1999; e) 2000; f) 2001; g) 2002 and h) 2003. 
The capacity of gillnet-based fisheries to maintain economic viability is (driven by the increased harvest of more abundant, but lower value species such as Prochilodus mariae), while populations of higher valued species such as $P$. metaense and other large catfishes are depleted. Because of this, careful monitoring of abundance and age structure of the $P$. metaense population will be required, particularly where gillnet-based fisheries are operating.

Pseudoplatystoma metaense have a hybrid life strategy, partly "seasonal" and partly "equilibrium" and hence they are vulnerable to overfishing as a consequence of slow growth, extended longevity, and low rates of natural mortality (Winemiller, 1989). If this species has no refuge from commercial fishermen, the traditional use of a legal minimum harvest size to increase recruitment to spawning sizes is not a practical option. The fishery resources of the Orinoco River Basin, of which $P$. metaense is a significant part, are currently being managed with a traditional fisheries management system, but without any clearly defined goals. The highly mobile and wide-ranging capacity of the commercial fleet requires a more complex and flexible management strategy to maintain future breeding stock and catches.

The incorporation of appropriately targeted spatial (fishing reserves) or temporal (closed season) restrictions within the existing effort management framework are likely to provide additional useful and robust mechanism to maintain spawning stock biomass and protect against recruitment overfishing (Pérez-Lozano, Barbarino, 2013). In the Orinoco River Basin, fishery managers should consider harvest strategies of low frequency or low intensity in conjunction with targeted spatial or temporal closures to protect the spawning stock biomass of all commercial species fish.

Harvest strategies such as setting fishing mortality at or near natural mortality $(F=M)$ might be an option. Recently, the adoption of harvest strategies such as setting $F=\mathrm{F}$ were thought to be quite conservative, but usually resulted in $F=M$ harvest strategies. Several authors have reported that optimal fishing mortality rates are substantially lower than natural mortality rates for most species and stocks (Walters, Martell, 2004). Furthermore, Patterson (1992) reported that fishing mortality rates above $2 / 3 M$ are often associated with stock declines, whereas fishing mortality rates below this level have resulted in stock recovery. Consequently, exploitation rates for long-lived large-bodied catfishes need to be very conservative.

The declines evident in the abundance of older ages of P. metaense in the landed catch (Fig. 4) support the finding of high levels of $F$. These data support the estimates of the annual percentage removals, indicating that the population of $P$. metaense in our study area (Fig. 1) is currently exploited above sustainable levels. The age structure of the exploited $P$. metaense stock within the Orinoco River Basin currently consists of about five age classes (ages 3 to 7 years). But from 1998 to 2003, the catch was strongly dominated by age 3 . Such depletion of the spawning stock biomass of these fishes will result in long population recovery times, and the economic loss associated with recovering and rebuilding these fisheries may persist longer. A minimum of five to seven years and a comprehensive fisheries management plan would be required for such an overfished population to recover in terms of both virgin spawner's biomass and age structure (Pérez et al., 2011).

An alternative solution could be the implementation of a hybrid fishery management system in the Orinoco River Basin that contemplates a large-scale adaptive and a microscale co-management approaches, including uncertainty and the participation of different stakeholders (Pérez et al., 2011). But before doing so, it is first necessary to support the efforts of fishermen to organize themselves to assign them adequate rights over the exploitation of fishery resources and to encourage governmental decentralization in decisionmaking on fishery resources in local administrative bodies, otherwise the fishery resources in general will continue in its low march towards its depletion.

\section{Acknowledgments}

The authors gratefully acknowledge funding from the Fondo Nacional de Ciencia y Tecnologia (FONACIT) for this project. This work was undertaken as part of Project S1-99000994. Logistical support was provided by the Universidad Nacional Experimental de los Llanos Occidentales "Ezequiel" Zamora (UNELLEZ) and Universidade Federal do Amazonas (UFAM). The authors are thankful to the fishermen of the Apure River Pedro Carrillo and Daniel Carrillo for providing samples and to fish wholesalers of Municipal Market of San Fernando de Apure). Hender Castillo and Rafael Tovar provided invaluable support in all field trips, and Gabriel Carrillo reviewed the English version of the manuscript.

\section{References}

Allan JD, Abell R, Hogan Z, Revenga C, Taylor BW, Welcomme $\mathrm{RL}$, Winemiller KO. Overfishing of inland waters. BioScience. 2005; 55(12):1041-51.

Ambrósio AM, Gomes LC, Agostinho AA. Age and growth of the Hypophthalmus edentatus (Spix), (Siluriformes, Hypophthalmidae) in the Itaipu Reservoir, Paraná, Brazil. Rev Bras Zool. 2003; 20(2):183-90.

Angelini R, Lucas AFB, Petrere Júnior M, Bortolini RC, Marco P. Ajuste do modelo de regressão periódica para predizer a temperatura média mensal da água em viveiros do CEPTA Pirassununga, SP Brasil. B Téc CEPTA. 1992; 5(1):31-39.

Balboni L, Colautti DC, Baigún CRM. Biology of growth of Hoplias aff. malabaricus (Bloch, 1794) in a shallow pampean lake (Argentina). Neotrop Ichthyol. 2011; 9(2):437-44.

Barbarino A. Aspectos biológicos y pesqueros de los bagres rayados Pseudoplatystoma fasciatum y P. tigrinum (Valenciennes 1840) (Siluriformes: Pimelodidae) en la parte baja de los ríos Apure y Arauca, Venezuela. Mem Fund La Salle Cien Nat. 2005; 163(1):71-91. 
Barbarino Duque A, Winemiller KO. Dietary segregation among large catfishes of the Apure and Arauca rivers, Venezuela. J Fish Biol. 2003; 63(2):410-27.

Beamish RJ, Fournier DA. A method for comparing the precision of a set of age determinations. Can J Fish Aquat Sci. 1981; 38(8):982-83.

Bliss CI. Statistics in biology. New York: McGraw-Hill Book Company; 1970.

Brothers EB. Summary of round table discussions on age validation. In: Prince ED, Pulos LM, editors. Proceedings of the International workshop on age determination of oceanic pelagic fishes: tunas, billfishes, and sharks. Miami (FL): National Marine Fisheries Service, NOAA; 1983. (NOAA Technical Report NMFS; vol 8).

Buitrago-Suárez UA, Burr BM. Taxonomy of the catfish genus Pseudoplatysoma Bleeker (Siluriformes: Pimelodidae) with recognition of eight species. Zootaxa. 2007; 1512(1):1-38.

Castillo O, Valdez E, Ortiz N, Moscó M. Aspectos sobre la historia natural de los bagres comerciales del bajo llano. In: Memorias del Congreso Iberoamericano y del Caribe Mem Fund La Salle Cien Nat. 1988; XLVIII (Suppl.2):253-57.

Chilton DE, Beamish RJ. Age determination methods for fishes studied by the Groundfish Program at the Pacific Biological Station. Ottawa: Government of Canada Fisheries and Oceans; 1982. (Canadian Special Publication of Fisheries and Aquatic Sciences; vol 60).

Fabré NN, Saint-Paul U. Annulus formation on scales and seasonal growth of the Central Amazonian anostomid Schizodon fasciatus. J Fish Biol. 1998; 53(1):1-11.

García Vasquéz A, Alonso JC, Carvajal F, Moreau J, Nuñez J, Renno JF, Tello S, Montreuil V, Duponchelle F. Life-history characteristics of the large Amazonian migratory catfish Brachyplatystoma rousseauxii in the Iquitos region, Peru. J Fish Biol. 2009; 75(10):2527-51.

King M. Fisheries biology: assessment and management. Oxford: Fishing News Books; 1995.

Kleinbaum DG, Kupper LL, Muller KE. Applied regression analysis and others multivariable methods. Boston (MA): PWS Publishing Co.; 1988.

Loubens G, Panfili J. Biologie de Pseudoplatystoma fasciatum et $P$. tigrinum (Teleostei: Pimelodidae) dans le bassin du Mamoré (Amazonie Bolivienne). Ichthyol Explor Freshwaters. 2000;11(1):13-34.

Machado-Allison A. Los peces de los llanos de Venezuela: un ensayo sobre su historia natural. Caracas: Universidad Central de Venezuela, Consejo de Desarrollo Científico y Humanístico; 1987.

Marriott R, Cappo M. Comparative precision and bias of five different ageing methods for the large tropical snapper Lutjanus johnii. Asian Fish Sci. 2000; 13(2000):149-60.

Mateus LAF, Petrere Júnior M. Age, growth and yield per recruit analysis of the pintado Pseudoplatystoma coruscans in the Cuiabá river basin, Pantanal Matogrossense, Brazil. Braz J Biol. 2004; 64(2):257-64.

Novoa DF. Los recursos pesqueros del eje fluvial OrinocoApure: presente y futuro. Caracas: Ministerio de Agricultura y Tierra; 2002.

van Overzee HMJ, Rijnsdorp AD. Effects of fishing during the spawning period: implications for sustainable management. Rev Fish Biol Fisher. 2015; 25(1):65-83.

Panfili J, De Pontual H, Troadec H, Wright PJ, editors. Manual of fish sclerochronology. Brest, France: Ifremer-IRD; 2002.
Patterson K. Fisheries for small pelagic species: an empirical approach to management targets. Rev Fish Biol Fisher. 1992; 2(4):321-38.

Penha JMF, Mateus LAF, Barbieri G. Age and growth of the duckbill catfish (Sorubim cf. lima) in the Pantanal. Braz J Biol. 2004a; 64(1):125-34.

Penha JMF, Mateus LAF, Barbieri G. Age and growth of the porthole shovelnose catfish (Hemisorubim platyrhynchos) in the Pantanal. Braz J Biol. 2004b; 64(4):833-40.

Pérez A, Barbarino A, Castillo O, Fabré N. Hacia un manejo pesquero integral en la cuenca del río Apure, Venezuela. Interciencia. 2011; 36(6):463-70.

Pérez A, Castillo O, Barbarino A, Fabré N. Aspectos reproductivos del bagre rayado Pseudoplatystoma tigrinum (Siluriformes: Pimelodidae) en la cuenca del río Apure, Venezuela. Zootecnia Trop. 2012; 30(3):251-62.

Pérez A, Fabré NN. Seleção das estruturas calcificadas para a determinação da idade da piracatinga Calophysus macropterus Lichtenstein (Siluriformes: Pimelodidade) na Amazônia Central, Brasil. Acta Amaz. 2003; 33(3):499-514.

Pérez-Lozano A, Barbarino A. Parámetros poblacionales de los principales recursos pesqueros de la cuenca del río Apure, Venezuela (2000-2003). Lat Am J Aquat Res. 2013; 41(3):447-58.

Reid S. La biología de los bagres rayados (Pseudoplatystoma fasciatum y $P$. tigrinum) en la cuenca del río Apure, Venezuela. Rev UNELLEZ Cienc Tecnol. 1983; 1(1):13-41.

Ruffino ML, Isaac VJ. Dinâmica populacional do surubim-tigre Pseudoplatystoma tigrinum (Valenciennes, 1840) no médio Amazonas (Siluriformes, Pimelodidae). Acta Amaz. 1999; 29(3):463-76.

Sokal RR, Rolf FJ. Biometry: the principles and practice of statistics in biological research. New York: W.H. Freeman and Company; 1981.

Sparre P, Verema SC. Introducción a la evaluación de recursos pesqueros tropicales, parte 1: manual. Rome: Organización de las Naciones Unidas para la Agricultura y la Alimentación (FAO); 1995. (FAO Documento Técnico de Pesca; No. 306/1, Rev. 2).

Stergiou IK. Overfishing, tropicalization of fish stocks, uncertainty and ecosystem management: resharpening Ockham's Razor. Fish Res. 2002; 55(1-3):1-9.

Tesch FW. Age and growth. In: Ricker WE, editor. Methods for assessment of fish production in freshwaters. 2nd ed. Oxford: Blackwell Scientific Publications; 1971. p.99-130.

Volpedo AV, Vaz-dos-Santos AM, editors. Métodos de estudios con otolitos: principios y aplicaciones. Ciudad Autónoma de Buenos Aires: INPA CONICET UBA; 2015.

Walters CJ, Martell SJD. Fisheries ecology and management. New Jersey: Princeton University Press; 2004.

Winemiller KO. Patterns of variation in life history among South American fishes in seasonal environments. Oecologia. 1989; 81(2):225-41.
Submitted September 30, 2016 Accepted by February 18, 2018 by Paulo Pompeu 
